OPEN ACCESS

Edited by:

Indrani Karunasagar,

Nitte University, India

Reviewed by:

Ahmed Askora,

Zagazig University, Egypt

D. Ipek Kurtböke,

University of the Sunshine Coast,

Australia

*Correspondence:

Chia Wanq Tan

chiawanq@gmail.com

Yaya Rukayadi

yaya_rukayadi@upm.edu.my

Specialty section:

This article was submitted to

Virology,

a section of the journal

Frontiers in Microbiology

Received: 12 October 2020

Accepted: 19 February 2021

Published: 10 March 2021

Citation:

Tan CW, Rukayadi Y, Hasan H,

Abdul-Mutalib N-A, Jambari NN, Hara H, Thung TY, Lee E and Radu S (2021) Isolation and Characterization of Six Vibrio parahaemolyticus Lytic

Bacteriophages From

Seafood Samples.

Front. Microbiol. 12:616548.

doi: $10.3389 /$ fmicb.2021.616548

\section{Isolation and Characterization of Six Vibrio parahaemolyticus Lytic Bacteriophages From Seafood Samples}

\author{
Chia Wanq Tan ${ }^{*}$, Yaya Rukayadi*, Hanan Hasan', Noor-Azira Abdul-Mutalib 1,2, \\ Nuzul Noorahya Jambari1,2, Hirofumi Hara ${ }^{3}$, Tze Young Thung ${ }^{4}$, Epeng Lee ${ }^{2}$ and \\ Son Radu ${ }^{1,2}$
}

\footnotetext{
'Department of Food Science, Faculty of Food Science and Technology, Universiti Putra Malaysia, UPM Serdang, Selangor, Malaysia, ${ }^{2}$ Food Safety and Food Integrity, Institute of Tropical Agriculture and Food Security (ITAFoS), Universiti Putra Malaysia, UPM Serdang, Selangor, Malaysia, ${ }^{3}$ Department of Environmental Engineering and Green Technology, Malaysia-Japan International Institute of Technology, Universiti Teknologi Malaysia, Kuala Lumpur, Malaysia, ${ }^{4}$ Infection and Immunity Program, Department of Microbiology, Biomedicine Discovery Institute, Monash University, Clayton, VIC, Australia
}

Vibrio parahaemolyticus is a foodborne pathogen that is frequently isolated from a variety of seafood. To control this pathogenic Vibrio spp., the implementation of bacteriophages in aquaculture and food industries have shown a promising alternative to antibiotics. In this study, six bacteriophages isolated from the seafood samples demonstrated a narrow host range specificity that infecting only the $V$. parahaemolyticus strains. Morphological analysis revealed that bacteriophages Vp33, Vp22, Vp21, and Vp02 belong to the Podoviridae family, while bacteriophages Vp08 and Vp11 were categorized into the Siphoviridae family. All bacteriophages were composed of DNA genome and showed distinctive restriction fragment length polymorphism. The optimal $\mathrm{MOI}$ for bacteriophage propagation was determined to be 0.001 to 1 . One-step growth curve revealed that the latent period ranged from 10 to $20 \mathrm{~min}$, and the burst size of bacteriophage was approximately 17 to $51 \mathrm{PFU} / \mathrm{cell}$. The influence of temperature and $\mathrm{pH}$ levels on the stability of bacteriophages showed that all bacteriophages were optimally stable over a wide range of temperatures and $\mathrm{pH}$ levels. In vitro Iytic activity of all bacteriophages demonstrated to have a significant effect against V. parahaemolyticus. Besides, the application of a bacteriophage cocktail instead of a single bacteriophage suspension was observed to have a better efficiency to control the growth of $V$. parahaemolyticus. Results from this study provided a basic understanding of the physiological and biological properties of the isolated bacteriophages before it can be readily used as a biocontrol agent against the growth of $V$. parahaemolyticus. 


\section{INTRODUCTION}

Vibrio parahaemolyticus is a Gram-negative halophilic bacterium, which occurs naturally in marine environments. It is recognized as a leading foodborne pathogen that is frequently isolated from a variety of seafood (Wang et al., 2015). Consumption of food contaminated with $V$. parahaemolyticus can cause gastroenteritis, which is often displayed through bouts of abdominal pain, diarrhea, fever, and nausea. An open wound in the skin which comes in contact with $V$. parahaemolyticus can also result in wound infection. In rare instances, $V$. parahaemolyticus can cause life-threatening conditions like rapid necrosis of subcutaneous tissue and septicemia (Tena et al., 2010; Ahmad et al., 2013; Zhang and Orth, 2013). However, not all V. parahaemolyticus strains are pathogenic and capable of causing illness in humans (Elmahdi et al., 2016). The presence of thermostable direct hemolysin (TDH) and the TDH-related hemolysin (TRH) has been identified as well-known pathogenic factors in $V$. parahaemolyticus which cause vibriosis. Both $t d h$ and trh genes are therefore widely used as a virulence marker in many studies for the detection of pathogenic V. parahaemolyticus strains (Chen et al., 2016; Kang et al., 2017; Paria et al., 2019). However, infection caused by $V$. parahaemolyticus strains without the virulence $t d h$ and trh genes have been reported in numerous studies (Bhoopong et al., 2007; Jones et al., 2012; Li et al., 2014; Pazhana et al., 2014). The pathogenesis of $V$. parahaemolyticus is therefore still open to question and has not been fully elucidated.

Bacteriophages or phages are bacterial viruses that infect bacterial cells only. Bacteriophages can be found in ubiquitous environments and are recognized as the most abundant organisms with $10^{31}$ bacteriophage particles on the earth's surface (Comeau et al., 2008; Keen, 2015). Bacteriophages are typically highly host-specific, which targets only specific species or even strains (Hagens and Loessner, 2007). Besides, high specificity levels of bacteriophages could minimize the disturbance of commensal bacteria (Viazis et al., 2011). The International Committee on Taxonomy of Viruses (ICTV) is responsible for the classification and nomenclature of viruses based on their morphological, genomic and proteomic characteristics (Adams et al., 2017). Tailed bacteriophages are grouped into the order of Caudovirales which consist of three families Myoviridae, Podoviridae, and Siphoviridae. Today, the order of Caudovirales includes six subfamilies, 80 genera, and 441 species (Krupovic et al., 2016). In 2018 and 2019, an update from the ICTV has proposed the creation of a new order (Tubulavirales), 10 new families (Autographiviridae, Chaseviridae, Demerecviridae, Drexlerviridae, Finnlakeviridae, Halspiviridae, Herelleviridae, Ovaliviridae, Plectroviridae, and Thaspiviridae), 22 subfamilies, 424 genera, and 964 species (Adriaenssens et al., 2020).

Bacteriophages can be grouped into individual families based on their distinct morphological structure, as viewed through electron microscopy (Schramlová et al., 2010). Electron microscopy such as transmission electron microscopy (TEM) is typically used at the initial stage for rapid identification and characterization of viruses. Genetic materials of viruses can be either DNA or RNA, and the structure of the nucleic acid may be either single-stranded or double-stranded.
Restriction enzyme cleaves the DNA of bacteriophages into distinct polymorphism, which is known as restriction fragment length polymorphism (RFLP). The use of RFLP analysis can facilitate the study of genetic diversity and differentiate between individual bacteriophages. On the other hand, protein profiles of bacteriophages can be analyzed by sodium dodecyl sulfatepolyacrylamide gel electrophoresis (SDS-PAGE). SDS-PAGE analysis of phage structural proteins will reveal the molecular weight of phage proteins and help to determine the presence of phage structural proteins.

It is noteworthy that the discovery of bacteriophages occurred much earlier than antibiotics. The use of bacteriophage preparations in human trials have also been conducted for almost a century in Eastern Europe (Lin et al., 2017). Nevertheless, the development of a broad-spectrum of antibiotics later received more attention than the use of bacteriophages. Today, phage therapy involves the use of bacteriophages in clinical trials that have gained new attention due to the growing number of infections caused by multidrug-resistance bacteria (Rohde et al., 2018). Phage therapy against several bacterial pathogens in animal models have also been tested out and showed effective results in many studies (Biswas et al., 2002; Wang et al., 2006; Watanabe et al., 2007; Jun et al., 2014; Kalatzis et al., 2018).

The application of bacteriophages is not only limited to clinical trials to fight against bacterial infections. It can be used in livestock protection to reduce the mortality rate of animals as well as enhance the food safety levels by controlling the growth of foodborne pathogens. Globally, efforts to control Vibrio spp. with the application of bacteriophages in aquaculture settings have been reported by researchers. For example, Wang et al. (2017) demonstrated that the use of bacteriophage therapy in controlling $V$. harveyi within greenlip abalone. Le et al. (2020b) showed that the application of lytic bacteriophages in the reduction of oyster larvae mortality rate caused by $V$. alginolyticus. Le et al. (2020a) demonstrated that the effectiveness of bacteriophages treatment in the decontamination of Vibrio spp. in commercially produced microalgae that used as the primary food source for oyster larvae during hatchery culture. In the future, it is believed that the use of bacteriophages could be a promising alternative to antibiotics for fighting against bacterial pathogens.

In this study, the objective was to isolate $V$. parahaemolyticus bacteriophages from the seafood samples and the isolated bacteriophages were characterized based on host specificity, morphological, genomic character, protein profile, and temperature and $\mathrm{pH}$ stability. The in vitro lytic activity of single bacteriophage suspensions as well as the bacteriophage cocktails were also evaluated to determine their efficiency against the growth of $V$. parahaemolyticus.

\section{MATERIALS AND METHODS}

\section{Bacterial Strains}

Six V. parahaemolyticus strains which consisted of 4 clinical isolates and 2 food source isolates (non- $t d h$ and/or trh) were used as hosts for the isolation of bacteriophages (Table 1). PSU5333, PSU5322, and PSU4211 V. parahaemolyticus strains 
TABLE 1 | V. parahaemolyticus strains used for bacteriophages isolation.

\begin{tabular}{llcc}
\hline Isolate ID & Source & \multicolumn{2}{c}{ Pathogenic factor } \\
\cline { 3 - 4 } & & $\boldsymbol{t} \boldsymbol{d} \boldsymbol{h}$ & $\boldsymbol{t r h}$ \\
\hline PSU5333 & Clinical & + & - \\
PSU5322 & Clinical & + & + \\
PSU4211 & Clinical (O3:K6 serotype) & + & + \\
ATCC 17802 & ATCC & - & + \\
VP8 & Fish & - & - \\
VP11 & Fish & - & - \\
\hline
\end{tabular}

were kindly provided by Professor Dr. Varaporn Vuddhakul from the Prince of Songkla University, Thailand. V. parahaemolyticus ATCC 17802 was purchased from the American Type Culture Collection (ATCC), United States. Both VP8 and VP11 isolates were obtained from the laboratory stock strain at Food Safety Laboratory, Universiti Putra Malaysia. All bacterial strains used were confirmed by PCR amplification of species-specific toxR gene and pathogenicity $t d h$ and trh genes with specific primers as mentioned in the previous study (Tan et al., 2017) and the amplified sequences were further confirmed by DNA sequencing.

\section{Sample Preparation}

A total of 30 seafood samples consisting of 10 samples for each blood clam, shrimp, and surf clam were purchased from different wet markets in Selangor, Malaysia. Ten grams of each sample was then weighed and transferred into $10 \mathrm{~mL}$ of salt of magnesium (SM) buffer ( $100 \mathrm{mM} \mathrm{NaCl}, 8 \mathrm{mM} \mathrm{MgSO}{ }_{4} \cdot 7 \mathrm{H}_{2} \mathrm{O}$, $50 \mathrm{mM}$ pH 7.5 Tris- $\mathrm{HCl}$ and $0.01 \%$ gelatin [Merck, Germany]) in a $50 \mathrm{~mL}$ sterile centrifuge tube. The mixture was shaken at $150 \mathrm{rpm}$ for $15 \mathrm{~min}$ in an orbital shaker. Large particles were pelleted in the tube via centrifugation at $10,000 \times g$ for $5 \mathrm{~min}$. The supernatant was filtered through a $0.2 \mu \mathrm{M}$ pore size syringe filter (Pall, United States). A $200 \mu \mathrm{L}$ of log-phase $V$. parahaemolyticus host culture $\left(\mathrm{OD}_{600 \mathrm{~nm}}=0.4-0.6\right)$ was added into the $5 \mathrm{~mL}$ of filtrate and incubated at $37^{\circ} \mathrm{C}, 150 \mathrm{rpm}$ in an orbital shaker overnight. After incubation, the mixture was centrifuged at $10,000 \times g$ for 5 min to pelletize the bacterial cells and the supernatant was filtered with a $0.2 \mu \mathrm{M}$ pore size syringe filter (Pall, United States).

\section{Detection of the Presence of Bacteriophages}

Ten-fold serial dilutions (through $10^{-8}$ ) of the filtrate was prepared in SM buffer. Each of these different dilutions was screened for the presence of bacteriophage by spotting $10 \mu \mathrm{L}$ of the filtrate on a double-layer agar plate with a bacterial host (Beck et al., 2009). The plate was allowed to dry for at least $15 \mathrm{~min}$ and the plate was incubated in an inverted position at $37^{\circ} \mathrm{C}$ overnight. Lysis zone was observed after the incubation. Filtrate from the highest dilution which showed a clear lysis zone on the double-layer agar plate was selected for isolation, propagation, and purification.

\section{Isolation of Bacteriophage}

Isolation of bacteriophages was carried out according to the double agar overlay plaque assay (Kropinski et al., 2009). A $100 \mu \mathrm{L}$ of each dilution filtrate and $100 \mu \mathrm{L}$ of the logphase bacteria culture was aliquot into a $3 \mathrm{~mL}$ molten soft agar, which constituted of tryptic soy broth (TSB) (Merck, Germany) and $0.6 \%$ bacteriological agar (Merck, Germany), which was stored at $45^{\circ} \mathrm{C}$. The molten soft agar was mixed gently and poured evenly onto tryptic soy agar (TSA) (Merck, Germany) base plate. The plate was allowed to solidify for at least $15 \mathrm{~min}$ and incubated in an inverted position at $37^{\circ} \mathrm{C}$ overnight. After incubation, a single colony plaque with clear lysis appearance from the highest dilution was picked using a sterile inoculation loop and transferred it into a $5 \mathrm{~mL} \mathrm{SM}$ buffer with $200 \mu \mathrm{L}$ log-phase bacteria culture. The mixture was incubated at $37^{\circ} \mathrm{C}, 150 \mathrm{rpm}$ in an orbital shaker overnight. After incubation, the sample was centrifuged at $10,000 \times g$ for $5 \mathrm{~min}$, and the supernatant was filtered with a $0.2 \mu \mathrm{M}$ pore size syringe filter.

\section{Propagation and Precipitation of Bacteriophage}

Bacteriophage was amplified according to the phage propagation via liquid lysate as described by Bonilla et al. (2016) but with some modifications. Briefly, $200 \mathrm{~mL}$ of TSB supplemented with $0.001 \mathrm{M} \mathrm{CaCl}_{2}$ and $\mathrm{MgCl}_{2}$ was prepared in a $250 \mathrm{~mL}$ centrifuge bottle and spiked with 0.1 volumes of overnight bacteria host. A $200 \mu \mathrm{L}$ of bacteriophage lysate $\left(>10^{8} \mathrm{PFU} / \mathrm{mL}\right)$ was then added into the centrifuge bottle and incubated at $37^{\circ} \mathrm{C}, 150 \mathrm{rpm}$ in an orbital shaker until the lysate cleared. After incubation, the sample was centrifuged at $4^{\circ} \mathrm{C}$ and $4,000 \times g$ for $20 \mathrm{~min}$. The supernatant was filtered with a $0.2 \mu \mathrm{M}$ pore size syringe filter into a sterile centrifuge bottle. The filtrate was precipitated by adding 10\% (w/v) polyethylene glycol (PEG) 8000 (SigmaAldrich, United States) and kept undisturbed at $4^{\circ} \mathrm{C}$ for $24 \mathrm{~h}$. After $24 \mathrm{~h}$, the sample was centrifuged at $4^{\circ} \mathrm{C}$ and $4,000 \times g$ for $20 \mathrm{~min}$. The supernatant was removed, and the pellet was suspended in a $10 \mathrm{~mL}$ of SM buffer.

\section{Purification of Bacteriophage}

Bacteriophage suspension was purified using caesium chloride (CsCl) (Santa Cruz Biotechnology, United States) with a density gradient according to the method described in the T7 Select ${ }^{\circledR}$ System Manual TB178 (Novagen, United States). A $5 \mathrm{~mL}$ of bacteriophage suspension was aliquot slowly onto the uppermost layer and the sample was subjected to ultracentrifugation at $210,000 \times g$ and $4^{\circ} \mathrm{C}$ for $1 \mathrm{~h}$ in a Sorvall ${ }^{\mathrm{TM}} \mathrm{WX}$ ultracentrifuge with a swinging bucket TH-641 Rotor (Thermo Scientific, United States). After centrifugation, a sharp and turbid band containing the purified bacteriophage particles was collected carefully with a Pasteur pipet. The purified bacteriophage was subjected to dialysis to remove $\mathrm{CsCl}$ with an Amicon ${ }^{\circledR}$ Ultra15 100K filter device (Merck, Germany) and SM buffer (Bonilla et al., 2016). After dialysis, the purified bacteriophage was assayed to determine the bacteriophage titer. The purified bacteriophage stock sample was stored at $4^{\circ} \mathrm{C}$ until further analysis. 


\section{Host Range Specificity}

A total of 134 bacteria strains including $126 \mathrm{~V}$. parahaemolyticus strains and 8 non- $V$. parahaemolyticus strains were used to study the host range of the isolated bacteriophages. Non$V$. parahaemolyticus strains including of $V$. alginolyticus, $V$. cholerae, V. vulnificus, Escherichia coli, Listeria monocytogenes, Salmonella enterica serovar Typhimurium, Salmonella enterica serovar Enteritidis, and Staphylococcus aureus. Host range specificity was determined by spotting $20 \mu \mathrm{L}$ of each bacteriophage $\left(10^{5} \mathrm{PFU} / \mathrm{mL}\right)$ on a double-layer agar plate seeded with a bacteria strain (Viazis et al., 2011). The agar plate with bacteriophage inoculum was allowed to dry for at least $15 \mathrm{~min}$ before being incubated at $37^{\circ} \mathrm{C}$ overnight. Lysis zones were observed on the plate after the incubation.

\section{Transmission Electron Microscopy (TEM)}

Bacteriophage was visualized by a transmission electron microscope (TEM) as described by Kim et al. (2019) with some modifications. A carbon-coated copper grid was placed onto a drop of purified bacteriophage $\left(10^{10} \mathrm{PFU} / \mathrm{mL}\right)$ for $2 \mathrm{~min}$. The grid with the sample was negatively stained first with $2 \%(\mathrm{w} / \mathrm{v})$ uranyl acetate for $2 \mathrm{~min}$, followed by sterile water for $1 \mathrm{~min}$. The excess sample was removed with a filter paper, and the grid was allowed to air dry for $10 \mathrm{~min}$. The morphology of the bacteriophage was then visualized with a JEM-2100 200-kV transmission electron microscope (JEOL, Japan).

\section{Bacteriophage Genome Analysis}

Extraction of nucleic acids of bacteriophage was performed according to the protocol provided with the Wizard DNA CleanUp Kit (Promega, United States). For determination of the type of nucleic acids, $2 \mu \mathrm{L}$ of extracted bacteriophage nucleic acid was treated separately with $2 \mu \mathrm{L}$ of DNase I $(1 \mathrm{U} / \mu \mathrm{L})$ and RNase A $(10 \mathrm{mg} / \mathrm{mL})$ (Thermo Scientific, United States) for $30 \mathrm{~min}$ at $37^{\circ} \mathrm{C}$ (Topka et al., 2019). The treated sample was electrophoresed through $0.7 \%(\mathrm{w} / \mathrm{v})$ agarose gel at $100 \mathrm{~V}$ for $30 \mathrm{~min}$. The agarose gel was stained with ethidium bromide $(0.5 \mu \mathrm{g} / \mathrm{ml})$ (Merck, Germany) and visualized with Syngene GeneGenius BioImaging system, together with GeneSnap software (version 7.12.01) (Syngene, Cambridge, United Kingdom).

\section{Restriction Fragment Length Polymorphism (RFLP)}

Genomic DNA (1 $\mu \mathrm{g} / \mu \mathrm{L})$ of each bacteriophage was digested individually with EcoRI, HaeIII, HindIII, and SalI restriction enzymes (Promega, United States) according to the manufacturer's protocols and incubated at $37^{\circ} \mathrm{C}$ for $1 \mathrm{~h}$. The digested product was electrophoresed and visualized as mentioned in the above section.

\section{SDS-PAGE Analysis}

Protein profiles of bacteriophage were analyzed by onedimensional SDS-PAGE. Each purified bacteriophage $\left(10^{10} \mathrm{PFU} / \mathrm{mL}\right)$ sample was first solubilized by mixing an equal volume of $2 \times$ sample buffer solution $(0.125 \mathrm{M}$ Tris- $\mathrm{HCl}$, $4 \% \mathrm{w} / \mathrm{v}$ SDS, $20 \% \mathrm{v} / \mathrm{v}$ glycerol, $0.01 \% \mathrm{w} / \mathrm{v}$ bromophenol blue,
$10 \% \mathrm{v} / \mathrm{v} 2$-mercaptoethanol) and boiled at $95^{\circ} \mathrm{C}$ for $10 \mathrm{~min}$ (Guan et al., 2004). The solubilized sample was loaded into 5-15\% Bullet PAGE One Precast Gel (Nacalai Tesque, Japan) and electrophoresed in $1 \times$ running buffer solution $(0.25 \mathrm{~mol} / \mathrm{L}$ Tris, $1.92 \mathrm{~mol} / \mathrm{L}$ Glycine, and $10 \mathrm{~g} / \mathrm{L} \mathrm{SDS}$ ) at $200 \mathrm{~V}$ for $30 \mathrm{~min}$. The gel was stained with CBB Stain One Super (Nacalai Tesque, Japan) for $30 \mathrm{~min}$ and de-stained several times with deionized water.

\section{Multiplicity of Infection (MOI)}

The multiplicity of infection (MOI) of the bacteriophage was tested according to Liu et al. (2013) with some modifications. The log-phase bacteria host was first prepared and mixed with bacteriophage suspension at different ratios $(0.0001,0.001,0.01$, $0.1,1,10$, and $100 \mathrm{PFU} / \mathrm{CFU})$. After incubation at $37^{\circ} \mathrm{C}$ for $3.5 \mathrm{~h}$, the sample was centrifuged at $10,000 \times g$ for $5 \mathrm{~min}$. The supernatant was filtered with a $0.2 \mu \mathrm{M}$ pore size syringe filter and enumerated to determine the bacteriophage titer. Bacteriafree suspension and bacteriophage-free suspension was included in all the experiments as a control sample. An MOI ratio with the highest bacteriophage titer was considered as the optimal MOI.

\section{One-Step Growth Curve}

One-step growth curve of each bacteriophage was studied according to the protocol described by Hong et al. (2014). Briefly, bacteriophage suspension was mixed with $1 \mathrm{~mL}$ of logphase bacteria host culture at the optimal MOI ratio. The mixture was incubated at $37^{\circ} \mathrm{C}$ and $150 \mathrm{rpm}$ for $10 \mathrm{~min}$ to allow the adsorption of bacteriophages to the host cells before centrifuging at $10,000 \times g$ for $30 \mathrm{~s}$. The pellet was suspended in $10 \mathrm{~mL}$ of TSB and the suspension was incubated at $37^{\circ} \mathrm{C}$ and $150 \mathrm{rpm}$. A $100 \mu \mathrm{L}$ of sample was withdrawn at $10 \mathrm{~min}$ intervals up to a total period of $1 \mathrm{~h}$ and enumerated by double agar overlay plaque assay in duplicate. The latent period and burst size of the bacteriophage was evaluated from the onestep growth curve.

\section{Temperature and pH Stability}

Temperature and $\mathrm{pH}$ stability were tested according to the method described by Thung et al. (2017) with some modifications. The temperature stability of bacteriophage suspension in the SM buffer was tested at different temperatures $\left(-20,25,37,50,60\right.$, and $\left.70^{\circ} \mathrm{C}\right)$ and incubated for $2 \mathrm{~h}$. For $\mathrm{pH}$ stability, bacteriophage suspension was incubated at different $\mathrm{pH}$ ranges $(\mathrm{pH} 2,3,5,7,9$, and 11) for $2 \mathrm{~h}$. Bacteriophage suspension kept at $4^{\circ} \mathrm{C}$ in the $\mathrm{SM}$ buffer (pH7.5) was used as a control in this study. After incubation, the titer of bacteriophage was determined by double agar overlay plaque assay and the survival rate was calculated by dividing the bacteriophage titer after treatment with the initial bacteriophage concentration in the control sample (Liu et al., 2020).

\section{In vitro Lytic Activity}

In vitro lytic activity was determined individually for each bacteriophage (Vp33, Vp22, Vp21, Vp02, Vp08, and Vp11) against its respective bacterial host strain. Two bacteriophage 
cocktails (cocktails A and B) were also prepared and tested for their synergistic effect (Table 2). Bacteriophage cocktails were selected based on the host range specificity results in the section "Host Range Specificity." Cocktails A and B were prepared for targeting $V$. parahaemolyticus clinical strains and environmental strains, respectively. A $500 \mu \mathrm{L}$ of log-phase $V$. parahaemolyticus host culture was mixed with an equal volume of bacteriophage lysate $\left(\sim 1 \times 10^{6} \mathrm{PFU} / \mathrm{mL}\right)$. The mixture was incubated immediately at $37^{\circ} \mathrm{C}$. A $100 \mu \mathrm{L}$ sample of the mixture was withdrawn at $0,2,4,6$, and $24 \mathrm{~h}$, to determine the concentration of bacteria through spread plating onto a CHROMagar ${ }^{\mathrm{TM}}$ Vibrio $(\mathrm{CV})$ plate. The plate was allowed to dry for at least $5 \mathrm{~min}$ before inverting the plate for incubation.

TABLE 2 | Bacteriophage cocktail preparations.

\begin{tabular}{lll}
\hline $\begin{array}{l}\text { Bacteriophage } \\
\text { cocktails }\end{array}$ & $\begin{array}{l}\text { Combination of } \\
\text { bacteriophages }\end{array}$ & $\begin{array}{l}\text { Against combination of } \\
\text { bacterial host strains }\end{array}$ \\
\hline Cocktail A & Vp33, Vp22, Vp21, & PSU5333, PSU5322, \\
and Vp02 & PSU4211, and ATCC 17802 \\
Cocktail B & Vp08 and Vp11 & VP8 and VP11
\end{tabular}

\section{RESULTS}

\section{Screening of Bacteriophage}

A total of six bacteriophages displayed an ability to lyse $V$. parahaemolyticus host strains and caused lysis zones on the double-layer agar plate was discovered in the blood clam, shrimp, and surf clam samples. Out of 10 shrimp samples, four samples were found to have the presence of $V$. parahaemolyticus bacteriophages. Only one sample of blood clam and surf clam was detected with the presence of $V$. parahaemolyticus bacteriophages.

\section{Host Range Specificity}

Purified bacteriophages were tested for their host range specificity. Lysis zones were observed on 61 out of 126 (48.4\%) of the double-layer agar plate seeded with $V$. parahaemolyticus strains (Table 3). No lysis zones were observed on all non- $V$. parahaemolyticus (8/8) bacteria lawn agar plates. Bacteriophages Vp33, Vp22, Vp21, and Vp02, were found to be able to cause lysis zones on $18.3 \%(23 / 126)$ of $V$.parahaemolyticus strains agar plates, which included four clinical strains of $V$. parahaemolyticus. On the other hand, Vp08 and Vp11 were

TABLE 3 | Host range specificity on different $V$. parahaemolyticus strains.

\begin{tabular}{|c|c|c|c|c|c|c|c|c|c|}
\hline \multirow[t]{2}{*}{ Bacteria strain } & \multirow[t]{2}{*}{ Isolate ID } & \multirow[t]{2}{*}{ Number of Isolate } & \multicolumn{6}{|c|}{ Bacteriophage } & \multirow[t]{2}{*}{ Source } \\
\hline & & & Vp33 & Vp22 & Vp21 & Vp02 & Vp08 & Vp11 & \\
\hline \multirow{6}{*}{$\begin{array}{l}\text { Vibrio } \\
\text { parahaemolyticus }\end{array}$} & PSU5333, PSU5322, and PSU4211 & 3 & + & + & + & + & - & - & PSU \\
\hline & ATCC 17802 & 1 & + & + & + & + & - & - & ATCC \\
\hline & $\begin{array}{l}\text { BC29, SC12, SC24, SH2, SQ13, and } \\
\text { SQ28 }\end{array}$ & 6 & + & + & + & + & + & + & FSQL \\
\hline & $\begin{array}{l}\text { BC13, BC15, BC32, SC16, SC19, } \\
\text { SC27, SH11, SH13, SH23, SH27, } \\
\text { SH8, SQ20, and SQ22 }\end{array}$ & 13 & + & + & + & + & - & - & FSQL \\
\hline & $\begin{array}{l}\text { VP8, VP11, BC1, BC6, BC7, BC8, } \\
\text { BC9, BC10, BC11, BC18, SC17, } \\
\text { SC22, SC25, SC28, SC29, SC1, SC5, } \\
\text { SC7, SC8, SC11, SH1, SH10, SH12, } \\
\text { SH26, SH29, SQ1, SQ11, SQ12, } \\
\text { SQ14, SQ18, SQ19, SQ21, SQ23, } \\
\text { SQ24, SQ25, SQ26, SQ27, and SQ3 }\end{array}$ & 38 & - & - & - & - & + & + & FSQL \\
\hline & $\begin{array}{l}\text { BC12, BC16, BC17, BC19, BC2, } \\
\text { BC20, BC21, BC22, BC23, BC24, } \\
\text { BC25, BC26, BC27, BC28, BC3, } \\
\text { BC30, BC31, BC4, BC4, BC5, SC10, } \\
\text { SC13, SC14, SC15, SC18, SC2, } \\
\text { SC20, SC21, SC23, SC26, SC3, SC4, } \\
\text { SC6, SC7, SC9, SH14, SH15, SH16, } \\
\text { SH17, SH18, SH19, SH20, SH21, } \\
\text { SH22, SH24, SH25, SH28, SH3, } \\
\text { SH30, SH31, SH4, SH5, SH6, SH9, } \\
\text { SQ10, SQ15, SQ16, SQ17, SQ2, SQ4, } \\
\text { SQ5, SQ6, SQ7, SQ8, and SQ9 }\end{array}$ & 65 & - & - & - & - & - & - & FSQL \\
\hline
\end{tabular}

+ Bacteriophage isolated from the sample showed lysis spot.

- No bacteriophage isolated from the sample.

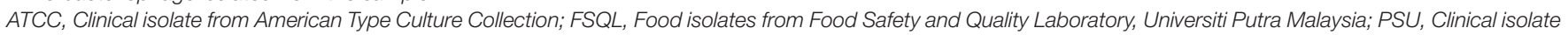
from Prince of Songkla University, Thailand. 
found to be able to cause lysis zones on $34.9 \%$ (44/126) of the environmental $V$. parahaemolyticus strains.

\section{Transmission Electron Microscopy (TEM)}

Electron microscopy revealed that the morphological characteristics of bacteriophages Vp33, Vp22, Vp21, and Vp02 were resembled Podoviridae family, and bacteriophages Vp08 and Vp11 were resembled Siphoviridae family (Figures 1A-F). Bacteriophages Vp33, Vp22, Vp21, and Vp02 were characterized with a hexagonal head diameter between $41.28 \pm 1.83$ to $50.00 \pm 3.21 \mathrm{~nm}$ and a short stumpy non-contractile tail diameter between $8.72 \pm 2.29$ to $12.44 \pm 2.30 \mathrm{~nm}$. Bacteriophages
Vp08 and Vp11 were exhibited with an elongated hexagonal head diameter between $79.00 \pm 5.94 \times 44.98 \pm 1.60 \mathrm{~nm}$ and $91.78 \pm 4.11 \times 49.54 \pm 2.05 \mathrm{~nm}$ and a long flexible non-contractile tail diameter between $133.79 \pm 15.98 \mathrm{~nm}$ and $142.24 \pm 13.47 \mathrm{~nm}$.

\section{Bacteriophage Genome Analysis}

From the determination of the nucleic acids, all the bacteriophage nucleic acids were digested by DNase I $(1 \mathrm{U} / \mu \mathrm{L})$ after $30 \mathrm{~min}$ incubation at $37^{\circ} \mathrm{C}$. None of the bacteriophage nucleic acids was digested by RNase A $(10 \mathrm{mg} / \mathrm{mL})$ after 30 min of incubation at $37^{\circ} \mathrm{C}$.
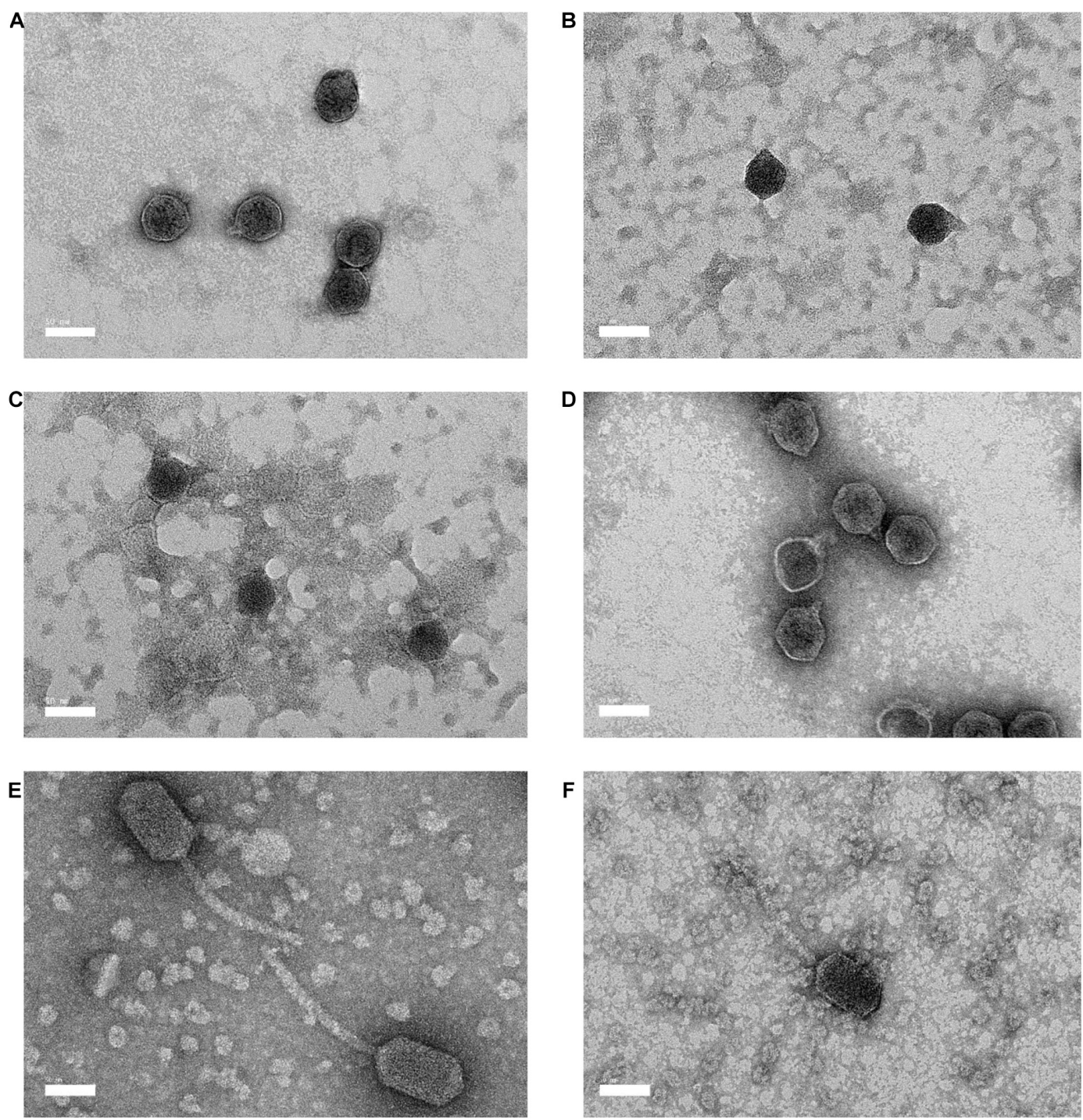

FIGURE 1 | Electron micrography of negative stained Vibrio parahaemolyticus bacteriophages and the bar represents $50 \mathrm{~nm}$. (A) Vp33 (head diameter: $44.70 \pm 2.30 \mathrm{~nm}$; tail diameter: $9.22 \pm 0.92 \mathrm{~nm}$ ); (B) Vp22 (head diameter: $41.28 \pm 1.83 \mathrm{~nm}$; tail diameter: $8.72 \pm 2.29 \mathrm{~nm}$ ); (C) Vp21 (head diameter: $42.63 \pm 2.07 \mathrm{~nm}$; tail diameter: $9.86 \pm 1.15 \mathrm{~nm}$ ); (D) Vp02 (head diameter: $50.00 \pm 3.21 \mathrm{~nm}$; tail diameter: $12.44 \pm 2.30 \mathrm{~nm}$ ); (E) Vp08 (head diameter: $91.78 \pm 4.11 \mathrm{~nm} \times 49.54 \pm 2.05 \mathrm{~nm}$; tail diameter: $142.24 \pm 13.47 \mathrm{~nm}$ ) (F) Vp11 (head diameter: $79.00 \pm 5.94 \mathrm{~nm} \times 44.98 \pm 1.60 \mathrm{~nm}$; tail diameter: $133.79 \pm 15.98 \mathrm{~nm})$. 


\section{Restriction Fragment Length Polymorphism (RFLP)}

From the restriction endonuclease digestion, the genomic DNA of all bacteriophages remained intact and unable to be digested by the EcoRI and SalI restriction enzymes. However, the genomic DNA of each bacteriophage treated with HindIII restriction enzyme produced a distinctive RFLP (Figure 2A). HaeIII restriction digestion profiles were also obtained for all bacteriophages except Vp08 and Vp11 (Figure 2B).

\section{SDS-PAGE Analysis}

Structural proteins of bacteriophages were analyzed by SDSPAGE. Protein profiles of bacteriophage Vp33, Vp22, Vp21, and $\mathrm{Vp} 02$ demonstrated a major protein band at around $31 \mathrm{kDa}$,
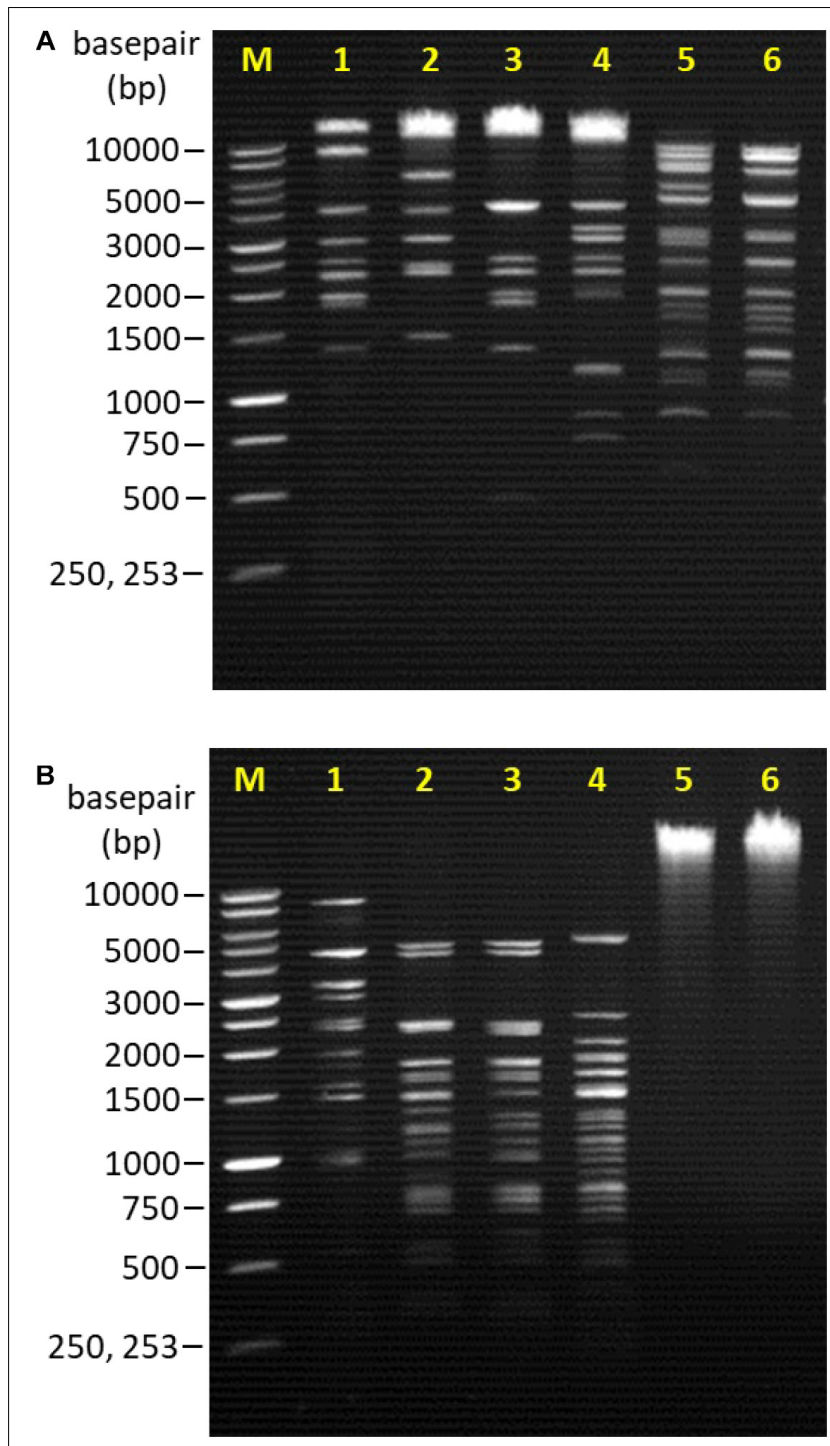

FIGURE 2 | Lane M: 1 kb DNA ladder (Promega, United States); Lane 1: Vp33; Lane 2: Vp22; Lane 3: Vp21; Lane 4: Vp02; Lane 5: Vp08; Lane 6: Vp11. (A) RFLP patterns of bacteriophages genomic DNA digested with Hindll. (B) RFLP patterns of bacteriophages genomic DNA digested with Haelll. while bacteriophages $\mathrm{Vp} 08$ and $\mathrm{Vp} 11$ exhibited a major protein band at around $40 \mathrm{kDa}$ (Figure 3). Bacteriophages Vp33, Vp22, and $\mathrm{Vp} 02$ were observed with similar protein profiles of 8 clear protein bands at around 36, 31, 26, 20,17, 15, 12, and $10 \mathrm{kDa}$. Bacteriophages Vp08 and Vp11 exhibited similar patterns of protein profiles with seven clear protein bands at around 48, 40, $26,20,17,10$, and $5 \mathrm{kDa}$. Bacteriophage Vp21 only showed two clear protein bands at around 35 and $32 \mathrm{kDa}$.

\section{Multiplicity of Infection (MOI)}

At an MOI of 1, bacteriophages Vp33, Vp08, and Vp11 exhibited the highest bacteriophage titer of $8.34 \pm 0.08,10.05 \pm 0.07$, and $9.47 \pm 0.15 \log \mathrm{PFU} / \mathrm{mL}$, respectively, after $3.5 \mathrm{~h}$ incubation at $37^{\circ} \mathrm{C}$. The MOI ratio of 1 was then determined to be the optimal MOI for the bacteriophages Vp33, Vp08, and Vp11. Bacteriophage Vp22 was observed with an optimal MOI of 0.001 from the highest bacteriophage titer of $9.52 \pm 0.06 \log \mathrm{PFU} / \mathrm{mL}$, while bacteriophage Vp02 was found with the optimal MOI of 0.1 from the highest bacteriophage titer of $10.02 \pm 0.11 \mathrm{log}$ $\mathrm{PFU} / \mathrm{mL}$. Lastly, the optimal MOI of bacteriophage Vp21 was determined to be 0.01 to 0.001 with the highest bacteriophage titer of $8.22 \pm 0.01$ and $8.22 \pm 0.03 \log \mathrm{PFU} / \mathrm{mL}$.

\section{One-Step Growth Curve}

From the one-step growth curve, all the bacteriophages were observed with a latent period of 20 min except bacteriophage Vp11 showed a faster latent period of $10 \mathrm{~min}$ in comparison to the others (Figures 4A-F). The average burst size of bacteriophages Vp33, Vp22, Vp21, Vp02, Vp08, and Vp11 estimated from the one-step growth curve were $22,51,34,26,37$, and 17 plaqueforming units (PFU) per cell, respectively.

\section{Temperature and pH Stability}

All bacteriophages were observed to remain relatively stable at temperatures $-20,25,37$, and $50^{\circ} \mathrm{C}$, with survival rate ranged from 93.13 to $100.00 \%$ (Table 4). At a temperature of $60^{\circ} \mathrm{C}$, a low survival rate of 31.16 and $49.96 \%$ was observed in bacteriophages $\mathrm{Vp} 08$ and $\mathrm{Vp} 11$, respectively. At a temperature of $70^{\circ} \mathrm{C}$, all bacteriophages were found inactivated and loss of infectivity. For $\mathrm{pH}$ stability, all bacteriophages were observed to be able to withstand a wide range of $\mathrm{pH}$ levels from 5 to 11 and found with a percentage of survival of 95.82 to $99.92 \%$ (Table 5). Besides, the majority of bacteriophages were found to be resistant at $\mathrm{pH} 3$ except that bacteriophages Vp21 and Vp22 were observed with a low survival rate of 47.15 and $52.64 \%$, respectively. At $\mathrm{pH} 2$, none of the bacteriophages was survived and recovered after a $2 \mathrm{~h}$ period of incubation.

\section{In vitro Lytic Activity}

All bacteriophages, including two bacteriophage cocktail preparations, were demonstrated to have significant $(P<0.05)$ in vitro lytic activity after $2 \mathrm{~h}$ incubation at $37^{\circ} \mathrm{C}$ (Table 6). The efficiency of single bacteriophage suspensions as well as the bacteriophage cocktails were also observed to increase significantly over time. The total reduction was reported to be in the range of $2.85 \pm 0.07$ to $4.60 \pm 0.08 \log \mathrm{CFU} / \mathrm{mL}$, for individual bacteriophage suspension. Bacteriophage cocktails A 


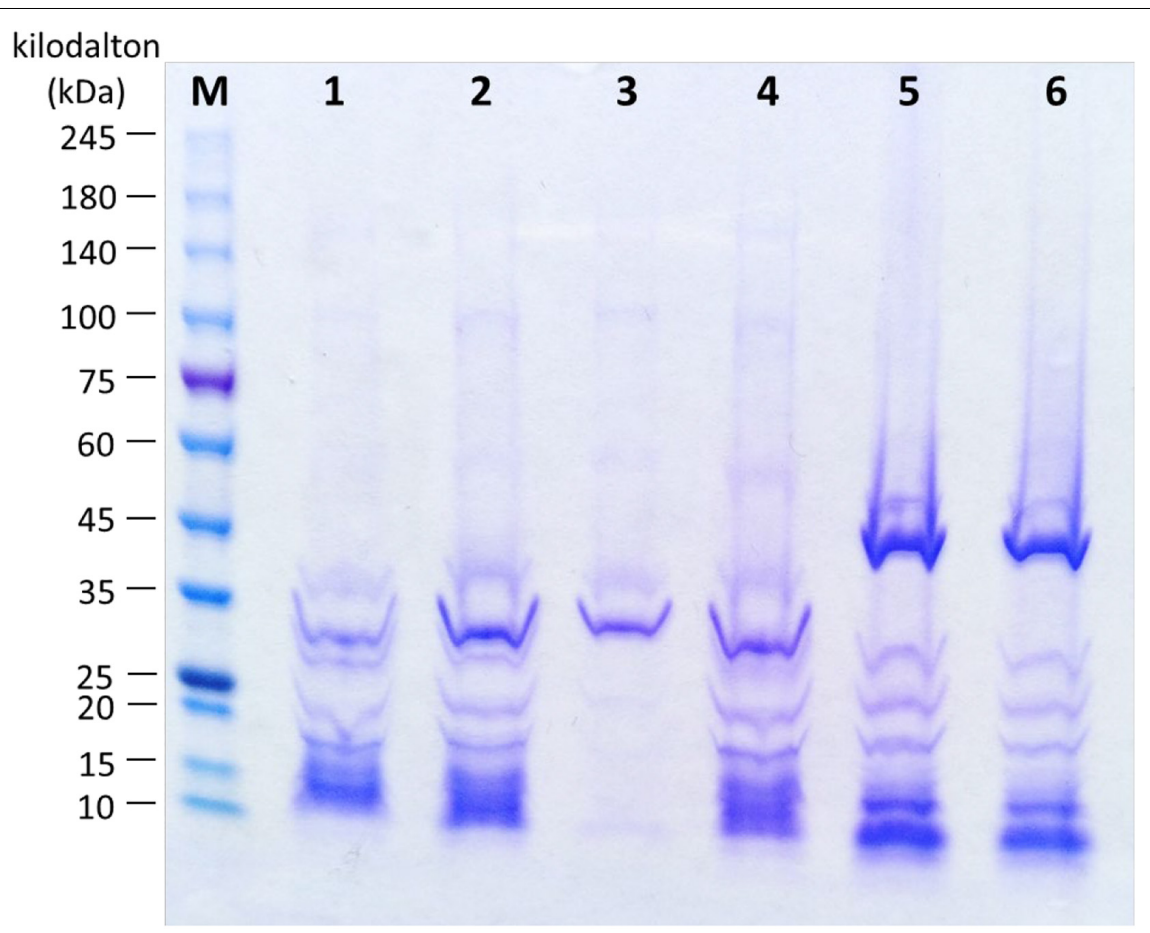

FIGURE 3 | Protein profiles of bacteriophages. Lane M: ExcelBand ${ }^{T M}$ High Range Protein Marker, PM2610 (SMOBIO, Taiwan); Lane 1: Vp33; Lane 2: Vp22; Lane 3: Vp21; Lane 4: Vp02; Lane 5: Vp08; Lane 6: Vp11.

and $\mathrm{B}$ achieved a better total reduction, with $3.69 \pm 0.49$ and $4.81 \pm 0.14 \log \mathrm{CFU} / \mathrm{mL}$, respectively.

\section{DISCUSSION}

The majority of studies were focused on the isolation of bacteriophages from environmental sources such as lake sediment, poultry farm, seawater, sewage, and soil (Salifu et al., 2013; Shende et al., 2017; Huang et al., 2018; Akhwale et al., 2019; Kim et al., 2019; Tang et al., 2019; Necel et al., 2020; Sevilla-Navarro et al., 2020). Reports of the isolation of these bacteriophages presence on fresh food samples were relatively limited in extent. According to Greer (2005), the successful isolation of bacteriophages from food samples was reliant on the occurrence of the target bacteria which was present in the food samples in relatively high concentrations.

Shrimp samples purchased from the wet markets were found to be the primary source of $V$. parahaemolyticus bacteriophages in this study. Similarly, several studies reported the isolation of Vibrio spp. bacteriophages from a similar source such as shrimp aquaculture environments (Alagappan et al., 2010; Stalin and Srinivasan, 2017; Matamp and Bhat, 2020). For instance, Alagappan et al. (2010) reported that five bacteriophages with the ability to infect $V$. parahaemolyticus MTCC-451 strain were isolated from the shrimp pond. Stalin and Srinivasan (2017) reported that bacteriophage VVP1 capable of infecting $V$. parahaemolyticus as well as $V$. alginolyticus strains were isolated from the water suspended sediment samples collected from the shrimp grow-out pond. Matamp and Bhat (2020) also reported that bacteriophages $\Phi \mathrm{VP}-1$ which able to lyse five strains of $V$. alginolyticus and 1 strain of $V$. parahaemolyticus were isolated from the shrimp pond water samples.

Host specificity of bacteriophage is one of the vital aspects which should be considered in a bacteriophage application. The specificity of bacteriophages isolated in this study were found to be of a narrow host range that infected only $V$. parahaemolyticus strains. A narrow host-specific bacteriophage seemed an attractive feature, especially when applying it in the gastrointestinal tract to target specific host bacteria as the narrow host range of the bacteriophage would not affect other endogenous bacteria (Viazis et al., 2011; Drulis-Kawa et al., 2012). Besides, different types of narrow host range bacteriophages can be mixed in a cocktail preparation for a more effective in vitro control of pathogenic bacteria (Tanji et al., 2004; Mapes et al., 2016; Bai et al., 2019).

Both the Podoviridae and Siphoviridae families are classified under the same order of Caudovirales. A hexagonal head (41.28 to $50.00 \mathrm{~nm}$ ) and a short stumpy non-contractile tail (8.72 to $12.44 \mathrm{~nm}$ ) which resembled the Podoviridae family was observed in the negative staining of bacteriophages Vp33, Vp22, Vp21, and Vp02 under TEM. Similarly, Zhang et al. (2018) reported that a $V$. parahaemolyticus bacteriophage $\mathrm{vB}_{-} \mathrm{VpaS} \_\mathrm{OMN}$ isolated from the seafood sample belonged to the Podoviridae family and was observed to have a $55 \mathrm{~nm}$ isometric capsid and a short tail of about $16 \mathrm{~nm}$. On the other hand, the electron micrographs of bacteriophages Vp08 and Vp11 showed an elongated hexagonal head $(79.00 \times 44.98$ to $91.78 \times 49.54 \mathrm{~nm})$ and a long flexible non-contractile tail (133.79 to $142.24 \mathrm{~nm}$ ). These morphological characteristics resemble those of the Siphoviridae family. A recent 

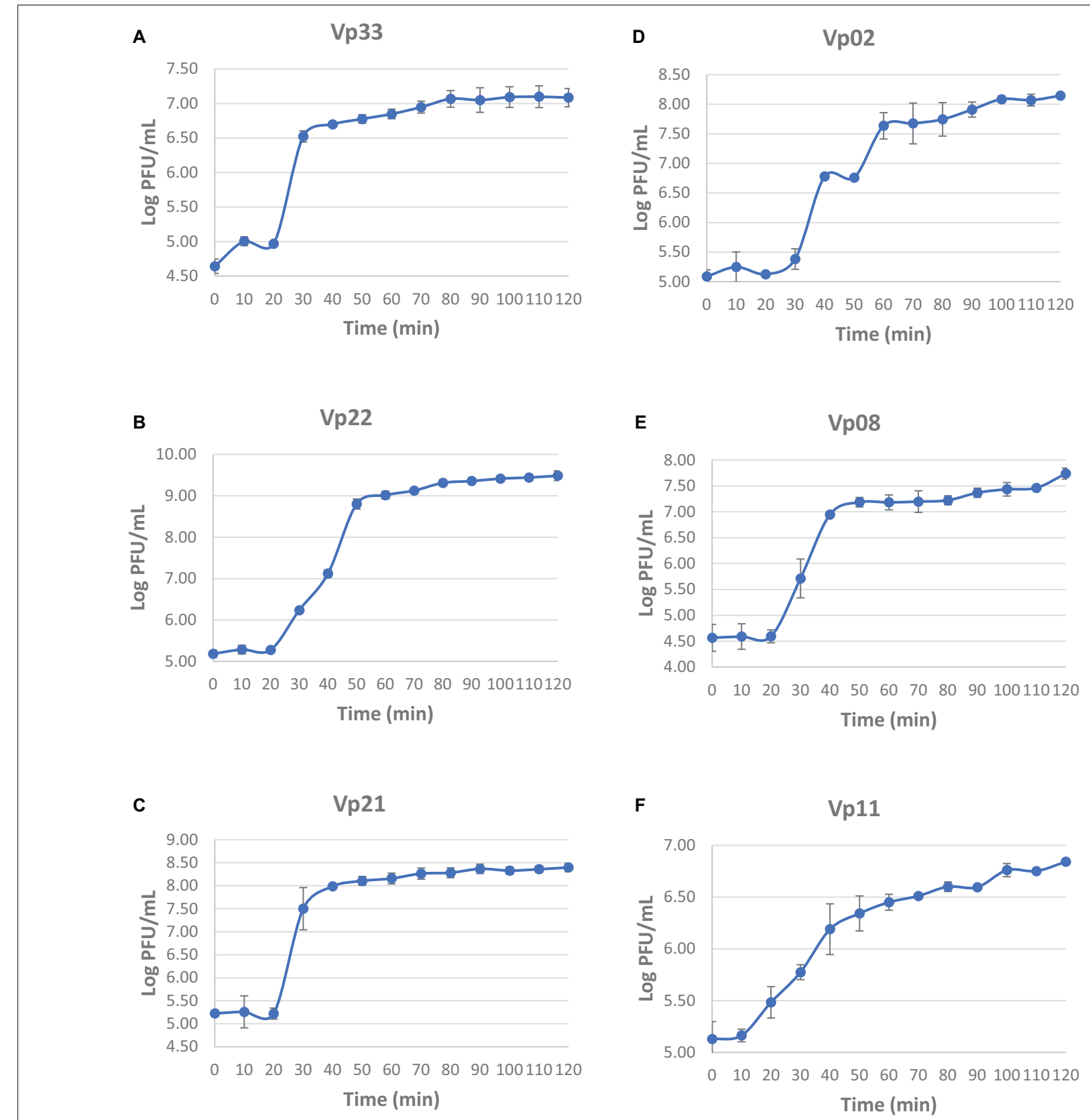

FIGURE 4 | One-step growth curve of bacteriophages. (A) Vp33; (B) Vp22; (C) Vp21; (D) Vp02; (E) Vp08; (F) Vp11.

study by Yang et al. (2020) reported a similar finding that two $V$. parahaemolyticus bacteriophages, namely vB_VpS_BA3 and vB_VpS_CA8, isolated from the sewage were Siphoviridae bacteriophage with an icosahedral head $(70 \times 55 \mathrm{~nm})$ and a long non-contractile tail (125 to $130 \mathrm{~nm})$.

Dion et al. (2020) reported that double-stranded DNA (dsDNA) tailed bacteriophages accounted for the majority of bacteriophages reported in the public database. This finding supports with Dion et al. (2020) statement as all bacteriophages in this study encapsulate a dsDNA genome. From the restriction endonuclease digestion, some genetic variation or polymorphisms were observed among bacteriophages.
Distinctive restriction digestion profiles between each bacteriophage isolates were observed after the genome of bacteriophages was digested by the HindIII and HaeIII restriction enzymes. From the restriction endonuclease digestion profiles, it can be concluded that all bacteriophage isolates analyzed in this study present some variation in their genetic properties.

A prominent protein band at around $31 \mathrm{kDa}$ was identified by SDS-PAGE analysis in all Podoviridae bacteriophages, Vp33, $\mathrm{Vp} 22, \mathrm{Vp} 21$, and Vp02. In contrast, bacteriophages Vp08 and Vp11 showed a prominent protein band at around $40 \mathrm{kDa}$. This prominent protein was assumed to be the major capsid protein of bacteriophage. In other studies, Drulis-Kawa et al. (2012) 
TABLE 4 | Temperature stability of bacteriophages.

\begin{tabular}{|c|c|c|c|c|c|c|}
\hline \multirow[t]{2}{*}{ Temperature } & \multicolumn{6}{|c|}{ Percentage of survival (\%) } \\
\hline & Vp33 & Vp22 & Vp21 & Vp02 & Vp08 & Vp11 \\
\hline$-20^{\circ} \mathrm{C}$ & $94.58 \pm 0.85$ & $96.09 \pm 0.11$ & $96.39 \pm 2.02$ & $93.13 \pm 1.56$ & $99.63 \pm 1.21$ & $97.67 \pm 1.22$ \\
\hline $25^{\circ} \mathrm{C}$ & $96.87 \pm 0.56$ & $95.61 \pm 0.38$ & $100.00 \pm 0.07$ & $93.89 \pm 1.46$ & $99.29 \pm 0.06$ & $99.93 \pm 0.17$ \\
\hline $37^{\circ} \mathrm{C}$ & $97.98 \pm 0.55$ & $97.90 \pm 0.75$ & $97.69 \pm 0.92$ & $95.60 \pm 1.42$ & $99.92 \pm 0.50$ & $99.38 \pm 0.01$ \\
\hline $50^{\circ} \mathrm{C}$ & $97.76 \pm 0.49$ & $97.62 \pm 0.05$ & $99.27 \pm 0.56$ & $95.69 \pm 0.51$ & $99.33 \pm 0.75$ & $98.79 \pm 0.56$ \\
\hline $60^{\circ} \mathrm{C}$ & $93.30 \pm 0.82$ & $95.54 \pm 0.72$ & $95.30 \pm 0.93$ & $91.15 \pm 1.25$ & $31.16 \pm 4.58$ & $49.96 \pm 2.60$ \\
\hline $70^{\circ} \mathrm{C}$ & 0.00 & 0.00 & 0.00 & 0.00 & 0.00 & 0.00 \\
\hline
\end{tabular}

TABLE 5 | pH stability of bacteriophages.

\begin{tabular}{|c|c|c|c|c|c|c|}
\hline \multirow[t]{2}{*}{ pH } & \multicolumn{6}{|c|}{ Percentage of survival (\%) } \\
\hline & Vp33 & Vp22 & Vp21 & Vp02 & Vp08 & Vp11 \\
\hline 2 & 0.00 & 0.00 & 0.00 & 0.00 & 0.00 & 0.00 \\
\hline 3 & $98.28 \pm 1.50$ & $52.64 \pm 7.31$ & $47.15 \pm 1.59$ & $94.30 \pm 1.15$ & $96.67 \pm 1.29$ & $94.94 \pm 0.81$ \\
\hline 5 & $99.54 \pm 0.13$ & $100.05 \pm 0.57$ & $99.36 \pm 0.45$ & $99.04 \pm 0.67$ & $97.52 \pm 0.21$ & $98.76 \pm 0.87$ \\
\hline 7 & $100.79 \pm 0.93$ & $98.68 \pm 0.49$ & $99.85 \pm 0.12$ & $97.58 \pm 0.74$ & $98.84 \pm 0.38$ & $102.21 \pm 0.22$ \\
\hline 9 & $99.92 \pm 0.02$ & $100.39 \pm 0.25$ & $99.82 \pm 0.33$ & $99.47 \pm 2.79$ & $95.82 \pm 0.59$ & $100.13 \pm 1.21$ \\
\hline 11 & $100.48 \pm 0.30$ & $100.57 \pm 0.00$ & $98.96 \pm 0.96$ & $100.10 \pm 0.22$ & $96.86 \pm 1.47$ & $99.35 \pm 0.53$ \\
\hline
\end{tabular}

TABLE 6 | Viable count (log CFU/mL) of $V$. parahaemolyticus after $0,2,4,6$, and $24 \mathrm{~h}$ incubation at $37^{\circ} \mathrm{C}$ with bacteriophage.

\begin{tabular}{|c|c|c|c|c|c|c|}
\hline \multirow[t]{2}{*}{ Sample } & \multicolumn{5}{|c|}{ Time (h) } & \multirow[t]{2}{*}{ Total Reduction (after 24 h) } \\
\hline & 0 & 2 & 4 & 6 & 24 & \\
\hline Vp33 & $7.08 \pm 0.15$ & $6.13 \pm 0.09$ & $5.73 \pm 0.20$ & $4.30 \pm 0.08$ & $3.70 \pm 0.34$ & $3.38 \pm 0.26$ \\
\hline Vp22 & $7.06 \pm 0.22$ & $6.06 \pm 0.11$ & $5.41 \pm 0.33$ & $5.02 \pm 0.17$ & $3.93 \pm 0.26$ & $3.20 \pm 0.25$ \\
\hline Vp21 & $7.13 \pm 0.11$ & $6.19 \pm 0.10$ & $5.63 \pm 0.07$ & $5.12 \pm 0.11$ & $4.07 \pm 0.12$ & $2.85 \pm 0.07$ \\
\hline Vp02 & $6.77 \pm 0.13$ & $5.93 \pm 0.09$ & $5.81 \pm 0.18$ & $5.13 \pm 0.15$ & $3.92 \pm 0.11$ & $2.98 \pm 0.22$ \\
\hline Vp08 & $7.81 \pm 0.18$ & $6.23 \pm 0.12$ & $5.52 \pm 0.09$ & $4.63 \pm 0.28$ & $3.59 \pm 0.25$ & $4.22 \pm 0.26$ \\
\hline Vp11 & $7.96 \pm 0.13$ & $6.33 \pm 0.04$ & $5.49 \pm 0.28$ & $4.62 \pm 0.10$ & $3.36 \pm 0.20$ & $4.60 \pm 0.08$ \\
\hline Cocktail A & $7.09 \pm 0.06$ & $6.11 \pm 0.10$ & $5.78 \pm 0.24$ & $4.09 \pm 0.07$ & $3.40 \pm 0.54$ & $3.69 \pm 0.49$ \\
\hline Cocktail B & $8.01 \pm 0.15$ & $6.15 \pm 0.21$ & $5.13 \pm 0.24$ & $4.33 \pm 0.10$ & $3.20 \pm 0.07$ & $4.81 \pm 0.14$ \\
\hline
\end{tabular}

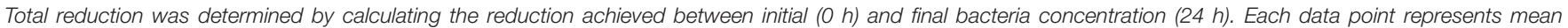
result \pm standard deviation in duplicates.

revealed a $39 \mathrm{kDa}$ major capsid protein in the Klebsiella pneumoniae podovirus bacteriophage, and this protein structure was found highly homologous $(78 \%)$ to the $37.8 \mathrm{kDa}$ Vibrio bacteriophage VP93 capsid protein. Baudoux et al. (2012) revealed that a Vibrio siphovirus bacteriophage SIO-2 was identified with the presence of a major capsid protein with a molecular mass of $29 \mathrm{kDa}$. Other protein bands may indicate the presence of putative tail fiber protein $(32.7 \mathrm{kDa})$, putative scaffolding protein $(30.1 \mathrm{kDa})$, putative internal virion protein B (20.4 kDa), hypothetical and/or unknown proteins of Vibrio bacteriophage (Drulis-Kawa et al., 2012; Hu et al., 2020).

Bacteriophages rely on the chance of meeting with bacteria to infect and kill bacteria (Huff et al., 2006). The MOI refers to the ratio of the virus particles to the host cells. In this study, the optimal MOI for bacteriophage propagation was determined to be 0.001 to 1 . Different bacteriophages may infect and kill bacteria differently, thus having different optimal MOIs. For example,
Yang et al. (2020) reported that two V. parahaemolyticus lytic bacteriophages, vB_VpS_BA3 and vB_VpS_CA8, were tested with optimal MOI of 0.1 from the maximum bacteriophage titer produced. A lytic bacteriophage PhVh6 showing the ability to lyse $V$. alginolyticus, $V$. harveyi, and $V$. parahaemolyticus was tested with an optimal MOI of 1 (Ibrahim et al., 2017).

From the one-step growth curve, the latent period of bacteriophages was estimated to be around 10 to $20 \mathrm{~min}$ and the average burst size was anticipated to be approximately 17 to $51 \mathrm{PFU} /$ cell. Previously, vibriophage BA3 and CA8 were estimated as having a latent period of around 20 to $30 \mathrm{~min}$ and a burst size of about 100 to 180 PFU/cell (Yang et al., 2020). Another lytic bacteriophage VP06 of $V$. parahaemolyticus was estimated to have a latent period of approximately $30 \mathrm{~min}$ and 60 PFU per infected bacterial cell (Wong et al., 2019). Lal et al. (2016) also reported that a $V$. parahaemolyticus bacteriophage VpKK5 exhibited a latent period of $36 \mathrm{~min}$ and a burst size 
of $180 \mathrm{PFU} /$ cell. From the results, bacteriophage isolates in this study demonstrated a shorter latent period but a smaller burst size than other reported vibrio bacteriophages.

Physico-chemical factors such as temperature and $\mathrm{pH}$ level can affect the effectiveness of bacteriophage applications against pathogenic bacteria (Ly-Chatain, 2014). For example, higher temperatures may result in irreversible damage or denaturation of the virus particles (Ahmadi et al., 2017). The concentration of hydrogen ions in an acidic solution can cause a decline in bacteriophage concentration due to the aggregation process (Langlet et al., 2007; Jończyk et al., 2011). In the current study, the effect of temperature on bacteriophage stability revealed that all bacteriophages remained relatively stable at temperatures ranging from -20 to $50^{\circ} \mathrm{C}$. At $60^{\circ} \mathrm{C}$, bacteriophages $\mathrm{Vp} 33, \mathrm{Vp} 22$, Vp21, and Vp02 which belong to the Podoviridae family showed continuing stability. In contrast, bacteriophages Vp08 and Vp11 which belong to the Siphoviridae family showed a low survival rate at $60^{\circ} \mathrm{C}$. Incubation at $70^{\circ} \mathrm{C}$ showed total inactivation of all bacteriophages. Previous studies reported a similar finding, in which $V$. parahaemolyticus bacteriophage VVP1 was found to be stable at temperatures 4 to $50^{\circ} \mathrm{C}$ but completely inactive at $60^{\circ} \mathrm{C}$ (Stalin and Srinivasan, 2017). Investigation of the effect of $\mathrm{pH}$ on bacteriophage stability revealed that all bacteriophages sustained well at $\mathrm{pH}$ ranges of 5 to 11 . At $\mathrm{pH} 3$, bacteriophages $\mathrm{Vp} 22$ and $\mathrm{Vp} 21$ were observed with a low survival percentage. At $\mathrm{pH} 2$, none of the bacteriophages survived this highly acidic environment. Such characteristics align with results reported by Jun et al. (2014) in which a bacteriophage $\mathrm{pVp}-1$, showed infectivity for multipleantibiotic-resistant $V$. parahaemolyticus and $V$. vulnificus, was observed to be stable over a wide range of $\mathrm{pH}$ levels of 3 to 11 .

Overall, the bacteriophage suspensions achieved an average $\log$ reduction of $V$. parahaemolyticus in the range of $2.85 \pm 0.07$ to $4.81 \pm 0.14$. Bacteriophage cocktail preparations were observed to have a better in vitro lytic activity as compared to a single bacteriophage suspension. However, other attributes such as competition between each $V$. parahaemolyticus strain and production of antagonistic compounds by $V$. parahaemolyticus strains that may exhibit antibacterial activity were excluded in the results and should be considered in the further study. Bacteriophage cocktail A achieved a total reduction rate of $3.69 \pm 0.49 \log \mathrm{CFU} / \mathrm{mL}$, compared to its individual bacteriophage suspension with a reduction rate between $2.85 \pm 0.07$ and $3.38 \pm 0.26 \log \mathrm{CFU} / \mathrm{mL}$. Bacteriophage cocktail $\mathrm{B}$ achieved a total reduction rate of $4.81 \pm 0.14 \log \mathrm{CFU} / \mathrm{mL}$, compared to its individual bacteriophage suspension with a reduction rate between $4.22 \pm 0.26$ and $4.60 \pm 0.08 \log \mathrm{CFU} / \mathrm{mL}$. According to these results, the application of a bacteriophage cocktail instead of a single bacteriophage suspension could therefore result in an improved reduction in the growth of $V$. parahaemolyticus.

Mateus et al. (2014) stated that the use of bacteriophage cocktails mixed with two or three bacteriophages can increase the efficiency to control and inactivate the growth of $V$. parahaemolyticus better than the single bacteriophage suspensions. For example, Mateus et al. (2014) reported that the application of bacteriophage cocktails mixed with the VP-1 and VP-2 bacteriophages achieved a maximum of $4.0 \mathrm{log}$ of $V$. parahaemolyticus inactivation after $2 \mathrm{~h}$ of incubation, compared to the use of VP-1 and VP-2 bacteriophage alone, with a reduction rate of only $0.8 \mathrm{log}$. Similarly, Ren et al. (2019) reported that a bacteriophage cocktail which consisted of PVP1 and PVP2 bacteriophages was superior in preventing $V$. parahaemolyticus infections in sea cucumbers than the use of single bacteriophages. It was also recently demonstrated that the benefit of bacteriophage cocktails can help to overcome the development of bacteriophage-resistant pathogen strains (Yang et al., 2020). For instance, Kim et al. (2020) demonstrated that a bacteriophage cocktail consists of three types of $V$. coralliilyticus-specific bacteriophages with greater efficiency against multiple-antibiotic-resistant (MAR) and phage-resistant (PR) V. coralliilyticus infection in oyster larvae. Yen et al. (2017) reported that a bacteriophage cocktail that targets different receptors on $V$. cholerae would reduce the emergence of bacteriophage-resistant $V$. cholerae isolates. Hence, bacteriophage cocktails consisting of multiple bacteriophage suspensions are more effective in the lytic ability.

\section{CONCLUSION}

Vibrio parahaemolyticus specific bacteriophages can be readily recovered from seafood samples. Bacteriophage Vp33, Vp22, Vp21, Vp02, Vp08, and Vp11 isolated from the seafood samples exhibited narrow host range and lytic activity against $V$. parahaemolyticus strains only. Characterization of bacteriophages in this study facilitates a better understanding of the physiological and biological features of bacteriophages. The results of in vitro lytic activity revealed the usability of bacteriophages as biocontrol agents for the control of $V$. parahaemolyticus.

\section{DATA AVAILABILITY STATEMENT}

The raw data supporting the conclusions of this article will be made available by the authors, without undue reservation.

\section{AUTHOR CONTRIBUTIONS}

NA-M, NJ, TT, and EL provided assistance and guidance throughout the research. YR, $\mathrm{HaH}, \mathrm{HiH}$, and SR were the mentor in the research study and assist in manuscript checking. All authors contributed to the article and approved the submitted version.

\section{FUNDING}

This work was supported by the Fundamental Research Grant Scheme (FRGS) of the Ministry of Higher Education (MOHE), Malaysia (FRGS/1/2018/STG05/UPM/01/7; 01-01-18-2015FR) and Grant Putra IPS from Universiti Putra Malaysia (GP-IPS 9438703). Publication of this work was funded by UPM Journal Publication Fund/Dana Penerbitan Jurnal UPM from Research Management Centre (RMC) of Universiti Putra Malaysia. 


\section{REFERENCES}

Adams, M. J., Lefkowitz, E. J., King, A. M., Harrach, B., Harrison, R. L., Knowles, N. J., et al. (2017). 50 years of the international committee on taxonomy of viruses: progress and prospects. Arch. Virol. 162, 1441-1446. doi: 10.1007/ s00705-016-3215-y

Adriaenssens, E. M., Sullivan, M. B., Knezevic, P., van Zyl, L. J., Sarkar, B. L., Dutilh, B. E., et al. (2020). Taxonomy of prokaryotic viruses: 2018-2019: update from the ICTV bacterial and archaeal viruses subcommittee. Arch. Virol. 165, 1253-1260. doi: 10.1007/s00705-020-04577-8

Ahmad, A., Brumble, L., and Maniaci, M. (2013). Vibrio parahaemolyticus induced necrotising fasciitis: an atypical organism causing an unusual presentation. Case Rep. Infect. Dis. 2013:216854. doi: 10.1155/2013/216854

Ahmadi, H., Radford, D., Kropinski, A. M., Lim, L. T., and Balamurugan, S. (2017). Thermal-stability and reconstitution ability of Listeria phages P100 and A511. Front. Microbiol. 8:2375. doi: 10.3389/fmicb.2017.02375

Akhwale, J. K., Rohde, M., Rohde, C., Bunk, B., Spröer, C., Boga, H. I., et al. (2019). Isolation, characterisation and analysis of bacteriophages from the haloalkaline lake Elmenteita, Kenya. PLoS One 14:e0215734. doi: 10.1371/journal.pone. 0215734

Alagappan, K. M., Deivasigamani, B., Somasundaram, S. T., and Kumaran, S. (2010). Occurrence of Vibrio parahaemolyticus and its specific phages from shrimp ponds in east coast of India. Curr. Opin. Microbiol. 61, 235-240. doi: 10.1007/s00284-010-9599-0

Bai, J., Jeon, B., and Ryu, S. (2019). Effective inhibition of Salmonella Typhimurium in fresh produce by a phage cocktail targeting multiple host receptors. J. Food Microbiol. 77, 52-60. doi: 10.1016/j.fm.2018.08.011

Baudoux, A. C., Hendrix, R. W., Lander, G. C., Bailly, X., Podell, S., Paillard, C., et al. (2012). Genomic and functional analysis of Vibrio phage SIO-2 reveals novel insights into ecology and evolution of marine siphoviruses. Environ. Microbiol. 14, 2071-2086. doi: 10.1111/j.1462-2920.2011.02685.x

Beck, N. K., Callahan, K., Nappier, S. P., Kim, H., Sobsey, M. D., and Meschke, J. S. (2009). Development of a spot-titer culture assay for quantifying bacteria and viral indicators. J. Rapid Methods Autom. Microbiol. 17, 455-464. doi: 10.1111/j.1745-4581.2009.00182.x

Bhoopong, P., Palittapongarnpim, P., Pomwised, P., Kiatkittipong, A., Kamruzzaman, M., Nakaguchi, Y., et al. (2007). Variability in properties of Vibrio parahaemolyticus strains isolated from single patients. J. Clin. Microbiol. 45, 1544-1550. doi: 10.1128/JCM.02371-06

Biswas, B., Adhya, S., Washart, P., Paul, B., Trostel, A. N., Powell, B., et al. (2002). Bacteriophage therapy rescues mice bacteremic from a clinical isolate of vancomycin-resistant Enterococcus faecium. Infect. Immun. 70, 204-210. doi: 10.1128/iai.70.1.204-210.2002

Bonilla, N., Rojas, M. I., Netto Flores, Cruz, G., Hung, S. H., Rohwer, F., et al. (2016). Phage on tap-a quick and efficient protocol for the preparation of bacteriophage laboratory stocks. PeerJ. 4:e2261. doi: 10.7717/peerj.2261

Chen, Y., Chen, X., Yu, F., Wu, M., Wang, R., Zheng, S., et al. (2016). Serology, virulence, antimicrobial susceptibility and molecular characteristics of clinical Vibrio parahaemolyticus strains circulating in southeastern China from 2009 to 2013. Clin. Microbiol. Infect. 22, 258.e9-258.e16. doi: 10.1016/j.cmi.2015.11.003

Comeau, A. M., Hatfull, G. F., Krisch, H. M., Lindell, D., Mann, N. H., and Prangishvili, D. (2008). Exploring the prokaryotic virosphere. Res. Microbiol. 159, 306-313. doi: 10.1016/j.resmic.2008.05.001

Dion, M. B., Oechslin, F., and Moineau, S. (2020). Phage diversity, genomics and phylogeny. Nat. Rev. Microbiol. 18, 125-138. doi: 10.1038/s41579-019-0311-5

Drulis-Kawa, Z., Majkowska-Skrobek, G., Maciejewska, B., Delattre, A. S., and Lavigne, R. (2012). Learning from bacteriophages - advantages and limitations of phage and phage-encoded protein applications. Curr. Protein Pept. Sci. 13, 699-722. doi: 10.2174/138920312804871193

Elmahdi, S., DaSilva, L. V., and Parveen, S. (2016). Antibiotic resistance of Vibrio parahaemolyticus and Vibrio vulnificus in various countries: a review. Food Microbiol. 57, 128-134. doi: 10.1016/j.fm.2016.02.008

Greer, G. G. (2005). Bacteriophage control of foodborne bacteria. J. Food Prot. 68, 1102-1111. doi: 10.4315/0362-028x-68.5.1102

Guan, S. M., Nagata, H., Maeda, K., Kuboniwa, M., Minamino, N., and Shizukuishi, S. (2004). Purification and characterization of a hemoglobin-binding outer membrane protein of Prevotella intermedia. FEMS Microbiol. Lett. 235, 333-339. doi: 10.1111/j.1574-6968.2004.tb09607.x
Hagens, S., and Loessner, M. J. (2007). Application of bacteriophages for detection and control of foodborne pathogens. Appl. Microbiol. Biotechnol. 76, 513-519. doi: 10.1007/s00253-007-1031-8

Hong, Y., Pan, Y., and Ebner, P. D. (2014). Meat science and muscle biology symposium: development of bacteriophage treatments to reduce Escherichia coli $\mathrm{O} 157: \mathrm{H} 7$ contamination of beef products and produce1. J. Anim. Sci. 92, 1366-1377. doi: 10.2527/jas.2013-7272

Hu, M., Zhang, H., Gu, D., Ma, Y., and Zhou, X. (2020). Identification of a novel bacterial receptor that binds tail tubular proteins and mediates phage infection of Vibrio parahaemolyticus. Emerg. Microbes Infect. 9, 855-867. doi: 10.1080/ 22221751.2020 .1754134

Huang, C., Virk, S. M., Shi, J., Zhou, Y., Willias, S. P., Morsy, M. K., et al. (2018). Isolation, characterisation, and application of bacteriophage LPSE1 against Salmonella enterica in ready to eat (RTE) foods. Front. Microbiol. 9:1046. doi: 10.3389/fmicb.2018.01046

Huff, W. E., Huff, G. R., Rath, N. C., and Donoghue, A. M. (2006). Evaluation of the influence of bacteriophage titer on the treatment of colibacillosis in broiler chickens. Poult. Sci. 85, 1373-1377. doi: 10.1093/ps/85.8.1373

Ibrahim, W. N. W., Aznan, A. S., Saari, N. A., Leong, L. K., Musa, N., Razzak, L. A., et al. (2017). In-vitro characterization of lytic bacteriophage PhVh6 as potential biocontrol agent against pathogenic Vibrio harveyi. Aquac. Aquar. Conserv. Legis. 10, 64-76.

Jończyk, E., Kłak, M., Międzybrodzki, R., and Górski, A. (2011). The influence of external factors on bacteriophages - review. Folia Microbiol. 56, 191-200. doi: 10.1007/s12223-011-0039-8

Jones, J. L., Ludeke, C. H., Bowers, J. C., Garrett, N., Fischer, M., Parsons, M. B., et al. (2012). Biochemical, serological, and virulence characterization of clinical and oyster Vibrio parahaemolyticus isolates. J. Clin. Microbiol. 50, 2343-2352. doi: 10.1128/JCM.00196-12

Jun, J. W., Shin, T. H., Kim, J. H., Shin, S. P., Han, J. E., Heo, G. J., et al. (2014). Bacteriophage therapy of a Vibrio parahaemolyticus infection caused by a multiple-antibiotic-resistant O3:K6 pandemic clinical strain. J. Infect. Dis. 210, 72-78. doi: 10.1093/infdis/jiu059

Kalatzis, P. G., Castillo, D., Katharios, P., and Middelboe, M. (2018). Bacteriophage interactions with marine pathogenic vibrios: implications for phage therapy. Antibiot. Basel 7:15. doi: 10.3390/antibiotics7010015

Kang, C. H., Shin, Y., Jang, S., Yu, H., Kim, S., An, S., et al. (2017). Characterisation of Vibrio parahaemolyticus isolated from oysters in Korea: resistance to various antibiotics and prevalence of virulence genes. Mar. Pollut. Bull. 118, 261-266. doi: 10.1016/j.marpolbul.2017.02.070

Keen, E. C. (2015). A century of phage research: bacteriophages and the shaping of modern biology. BioEssays 37, 6-9. doi: 10.1002/bies.201400152

Kim, H. J., Jun, J. W., Giri, S. S., Kim, S. G., Kim, S. W., Kwon, J., et al. (2020). Bacteriophage cocktail for the prevention of multiple-antibioticresistant and mono-phage-resistant Vibrio coralliilyticus infection in pacific oyster (Crassostrea gigas) larvae. Pathogens 9:813. doi: 10.3390/pathogens 9100831

Kim, S. G., Jun, J. W., Giri, S. S., Yun, S., Kim, H. J., Kim, S. W., et al. (2019). Isolation and characterisation of pVa-21, a giant bacteriophage with antibiofilm potential against Vibrio alginolyticus. Sci. Rep. 9:6284. doi: 10.1038/ s41598-019-42681-1

Kropinski, A. M., Mazzocco, A., Waddell, T. E., Lingohr, E., and Johnson, R. P. (2009). “"Enumeration of bacteriophages by double agar overlay plaque assay,,", in Bacteriophages: Methods in Molecular Biology, eds M. R. Clokie and A. M. Kropinski (Totowa, NJ: Humana Press), 69-76.

Krupovic, M., Dutilh, B. E., Adriaenssens, E. M., Wittmann, J., Vogensen, F. K., Sullivan, M. B., et al. (2016). Taxonomy of prokaryotic viruses: update from the ICTV bacterial and archaeal viruses subcommittee. Arch. Virol. 161, 1095-1099. doi: 10.1007/s00705-015-2728-0

Lal, T. M., Sano, M., and Ransangan, J. (2016). Genome characterization of a novel vibriophage VpKK5 (Siphoviridae) specific to fish pathogenic strain of Vibrio parahaemolyticus. J. Basic Microbiol. 56, 872-888. doi: 10.1002/jobm. 201500611

Langlet, J., Gaboriaud, F., and Gantzer, C. (2007). Effects of pH on plaque forming unit counts and aggregation of MS2 bacteriophage. J. Appl. Microbiol. 103, 1632-1638. doi: 10.1111/j.1365-2672.2007.03396.x

Le, T. S., Southgate, P. C., O’Connor, W., Abramov, T., Shelley, D. V., Vu, S., et al. (2020a). Use of bacteriophages to control Vibrio contamination of microalgae 
used as a food source for oyster larvae during hatchery culture. Curr. Microbiol. 77, 1811-1820. doi: 10.1007/s00284-020-01981-w

Le, T. S., Southgate, P. C., O'Connor, W., Vu, S. V., and Kurtböke, D. İ (2020b). Application of Bacteriophages to control Vibrio alginolyticus contamination in oyster (Saccostrea glomerata) larvae. Antibiotics 9:415. doi: 10.3390/ antibiotics 9070415

Li, Y., Xie, X., Shi, X., Lin, Y., Qiu, Y., Mou, J., et al. (2014). Vibrio parahaemolyticus, southern coastal region of China, 2007-2012. Emerg. Infect. Dis. 20, 685-688. doi: $10.3201 /$ eid2004.130744

Lin, D. M., Koskella, B., and Lin, H. C. (2017). Phage therapy: an alternative to antibiotics in the age of multi-drug resistance. World J. Gastrointest. Pharmacol. Ther. 8, 162-173. doi: 10.4292/wjgpt.v8.i3.162

Liu, A., Liu, Y., Peng, L., Cai, X., Shen, L., Duan, M., et al. (2020). Characterization of the narrow-spectrum bacteriophage LSE7621 towards Salmonella Enteritidis and its biocontrol potential on lettuce and tofu. LWT Food Sci. Technol. 118:108791. doi: 10.1016/j.lwt.2019.108791

Liu, W., Ye, D., Luo, Z., Yu, Y., and Gong, T. (2013). Isolation and characterisation of five lytic bacteriophages infecting a Vibrio strain closely related to Vibrio owensii. FEMS Microbiol. Lett. 348, 112-119. doi: 10.1111/1574-6968.12277

Ly-Chatain, M. H. (2014). The factors affecting effectiveness of treatment in phages therapy. Front. Microbiol. 5:1-7. doi: 10.3389/fmicb.2014.00051

Mapes, A. C., Trautner, B. W., Liao, K. S., and Ramig, R. F. (2016). Development of expanded host range phage active on biofilms of multi-drug resistant Pseudomonas aeruginosa. Bacteriophage 6:e1096995. doi: 10.1080/21597081. 2015.1096995

Matamp, N., and Bhat, S. G. (2020). Genome characterisation of novel lytic Myoviridae bacteriophage $\phi \mathrm{VP}-1$ enhances its applicability against MDRbiofilm-forming Vibrio parahaemolyticus. Arch. Virol. 165, 387-396. doi: 10. 1007/s00705-019-04493-6

Mateus, L., Costa, L., Silva, Y. J., Pereira, C., Cunha, A., and Almeida, A. (2014). Efficiency of phage cocktails in the inactivation of Vibrio in aquaculture. Aquaculture 42, 167-173. doi: 10.1016/j.aquaculture.2014.01.001

Necel, A., Bloch, S., Nejman-Faleńczyk, B., Grabski, M., Topka, G., Dydecka, A., et al. (2020). Characterization of a bacteriophage, vB_Eco4M-7, that effectively infects many Escherichia coli O157 strains. Sci. Rep. 10:3743. doi: 10.1038/ s41598-020-60568-4

Paria, P., Kunal, S. P., Behera, B. K., Mohapatra, P. K. D., Das, A., Parida, P. K., et al. (2019). Molecular characterisation and genetic diversity study of Vibrio parahaemolyticus isolated from aquaculture farms in India. Aquaculture 509, 104-111. doi: 10.1016/j.aquaculture.2019.04.076

Pazhana, G. P., Bhowmik, S. K., Ghosh, S., Guin, S., Dutta, S., Rajendran, $\mathrm{K}$, et al. (2014). Trends in the epidemiology of pandemic and nonpandemic strains of Vibrio parahaemolyticus isolated from diarrheal patients in Kolkata, India. PLoS Negl. Trop. Dis. 8:e2815. doi: 10.1371/journal.pntd.00 02815

Ren, H., Li, Z., Xu, Y., Wang, L., and Li, X. (2019). Protective effectiveness of feeding phage cocktails in controlling Vibrio parahaemolyticus infection of sea cucumber Apostichopus japonicus. Aquaculture 503, 322-329. doi: 10.1016/j. aquaculture.2019.01.006

Rohde, C., Wittmann, J., and Kutter, E. (2018). Bacteriophages: a therapy concept against multi-drug-resistant bacteria. Surg. Infect. 19, 737-744. doi: 10.1089/sur. 2018.184

Salifu, S. P., Casey, S. A. C., and Foley, S. (2013). Isolation and characterisation of soilborne virulent bacteriophages infecting the pathogen Rhodococcus equi. J. Appl. Microbiol. 114, 1625-1633. doi: 10.1111/jam.12194

Schramlová, J., Arientová, S., and Hulínská, D. (2010). The role of electron microscopy in the rapid diagnosis of viral infections-review. Folia Microbiol. 55, 88-101. doi: 10.1007/s12223-010-0015-8

Sevilla-Navarro, S., Catalá-Gregori, P., García, C., Cortés, V., and Marin, C. (2020). Salmonella Infantis and Salmonella Enteritidis specific bacteriophages isolated form poultry faeces as a complementary tool for cleaning and disinfection against Salmonella. Comp. Immunol. Microbiol. Infect. Dis. 68:101405. doi: 10.1016/j.cimid.2019.101405

Shende, R. K., Hirpurkar, S. D., Sannat, C., Rawat, N., and Pandey, V. (2017). Isolation and characterisation of bacteriophages with lytic activity against common bacterial pathogens. Vet. World 10, 973-978. doi: 10.14202/vetworld. 2017.973-978

Stalin, N., and Srinivasan, P. (2017). Efficacy of potential phage cocktails against Vibrio harveyi and closely related Vibrio species isolated from shrimp aquaculture environment in the south east coast of India. Vet. Microbiol. 207, 83-96. doi: 10.1016/j.vetmic.2017.06.006

Tan, C. W., Malcolm, T., Kuan, C. H., Thung, T. Y., Chang, W. S., Loo, Y. Y., et al. (2017). Prevalence and antimicrobial susceptibility of Vibrio parahaemolyticus isolated from short mackerels (Rastrelliger brachysoma) in Malaysia. Front. Microbiol. 8:1087. doi: 10.3389/fmicb.2017.01087

Tang, F., Zhang, P., Zhang, Q., Xue, F., Ren, J., Sun, J., et al. (2019). Isolation and characterisation of a broad-spectrum phage of multiple drug resistant Salmonella and its therapeutic utility in mice. Microb. Pathog. 126, 193-198. doi: 10.1016/j.micpath.2018.10.042

Tanji, Y., Shimada, T., Yoichi, M., Miyanaga, K., Hori, K., and Unno, H. (2004). Toward rational control of Escherichia coli O157:H7 by a phage cocktail. Appl. Microbiol. Biotechnol. 64, 270-274. doi: 10.1007/s00253-003-1438-9

Tena, D., Arias, M., Alvarez, B. T., Mauleon, C., Jimenez, M. P., and Bisquert, J. (2010). Fulminant necrotising fasciitis due to Vibrio parahaemolyticus. J. Med. Microbiol. 59, 235-238. doi: 10.1099/jmm.0.014654-0

Thung, T. Y., Premarathne, J. M. K. J. K., Chang, W. S., Loo, Y. Y., Chin, Y. Z., Kuan, C. H., et al. (2017). Use of a lytic bacteriophage to control Salmonella Enteritidis in retail food. LWT Food Sci. Technol. 78, 222-225. doi: 10.1016/j. lwt.2016.12.044

Topka, G., Bloch, S., Nejman-Faleńczyk, B., Gąsior, T., Jurczak-Kurek, A., Necel, A., et al. (2019). Characterization of bacteriophage vB-EcoS-95, isolated from urban sewage and revealing extremely rapid lytic development. Front. Microbiol. 9:3326. doi: 10.3389/fmicb.2018.03326

Viazis, S., Akhtar, M., Feirtag, J., and Brabban, A. D. (2011). Isolation and characterisation of lytic bacteriophages against enterohaemorrhagic Escherichia coli. J. Appl. Microbiol. 110, 1323-1331. doi: 10.1111/j.1365-2672.2011.04989.x

Wang, J., Hu, B. E. I., Xu, M., Yan, Q. U. N., Liu, S., Zhu, X., et al. (2006). Therapeutic effectiveness of bacteriophages in the rescue of mice with extended spectrum B-lactamase-producing Escherichia coli bacteremia. Int. J. Mol. Med. 17, 347-355. doi: 10.3892/ijmm.17.2.347

Wang, W., Li, M., and Li, Y. (2015). Intervention strategies for reducing Vibrio Parahaemolyticus in seafood: a review. J. Food Sci. 80, R10-R19. doi: 10.1111/ 1750-3841.12727

Wang, Y., Barton, M., Elliott, L., Li, X., Abraham, S., O’Dea, M., et al. (2017). Bacteriophage therapy for the control of Vibrio harveyi in greenlip abalone (Haliotis laevigata). Aquaculture 473, 251-258. doi: 10.1016/j.aquaculture.2017. 01.003

Watanabe, R., Matsumoto, T., Sano, G., Ishii, Y., Tateda, K., Sumiyama, Y., et al. (2007). Efficacy of bacteriophage therapy against gut-derived sepsis caused by Pseudomonas aeruginosa in mice. Antimicrob. Agents Chemother. 51, 446-452. doi: 10.1128/AAC.00635-06

Wong, H. C., Wang, T. Y., Yang, C. W., Tang, C. T., Ying, C., Wang, C. H., et al. (2019). Characterization of a lytic vibriophage VP06 of Vibrio parahaemolyticus. Res. Microbiol. 170, 13-23. doi: 10.1016/j.resmic.2018.07.003

Yang, M., Liang, Y., Huang, S., Zhang, J., Wang, J., Chen, H., et al. (2020). Isolation and characterization of the novel phages vB_VpS_BA3 and vB_VpS_CA8 for lysing Vibrio parahaemolyticus. Front. Microbiol. 11:259. doi: 10.3389/fmicb. 2020.00259

Yen, M., Cairns, L. S., and Camilli, A. (2017). A cocktail of three virulent bacteriophages prevents Vibrio cholerae infection in animal models. Nat. Commun. 8:14187. doi: 10.1038/ncomms14187

Zhang, H., Yang, Z., Zhou, Y., Bao, H., Wang, R., Li, T., et al. (2018). Application of a phage in decontaminating Vibrio parahaemolyticus in oysters. Int. J. Food Microbiol. 275, 24-31. doi: 10.1016/j.ijfoodmicro.2018.03.027

Zhang, L., and Orth, K. (2013). Virulence determinants for Vibrio parahaemolyticus infection. Curr. Opin. Microbiol. 16, 70-77. doi: 10.1016/j.mib.2013.02.002

Conflict of Interest: The authors declare that the research was conducted in the absence of any commercial or financial relationships that could be construed as a potential conflict of interest.

Copyright $(2021$ Tan, Rukayadi, Hasan, Abdul-Mutalib, Jambari, Hara, Thung, Lee and Radu. This is an open-access article distributed under the terms of the Creative Commons Attribution License (CC BY). The use, distribution or reproduction in other forums is permitted, provided the original author(s) and the copyright owner(s) are credited and that the original publication in this journal is cited, in accordance with accepted academic practice. No use, distribution or reproduction is permitted which does not comply with these terms. 